\title{
Influence of Retail Atmospherics as Nonverbal Communication on Purchase Behaviour in the Nigerian Retail Environment
}

\author{
Kizito Ogedi Alakwe \\ School of Media and Communication (SMC) \\ Pan-Atlantic University \\ Km 52 Ajah/Epe Express Road, Ibeju-Lekki, Lagos. \\ kizito.alakwe@pau.edu.ng \\ +234-802-304-2156 \\ Ngozi Okpara PhD. \\ School of Media and Communication (SMC) \\ Pan-Atlantic University \\ Km 52 Ajah/Epe Express Road, Ibeju-Lekki, Lagos. \\ nokpara@pau.edu.ng \\ +234-802-303-4916
}

Received 18 March 2017/ Revised: 21 April 2017/ Accepted: 10 May 2017/ Published online: 9 June 2017

\begin{abstract}
This paper focuses on unravelling the impact of atmospherics on shopper purchase behaviour in emerging markets like Nigeria and attempts to isolate the atmospheric cue that is the most significant predictor of shopper purchase decisions. The paper seeks to establish a correlation between the design, ambient and social cues in big shopping malls and buyer purchase behaviour. A quantitative and deductive approach is adopted. Data collection is through a survey, and the principal research instrument is the questionnaire. Results reveal that retail atmospherics exert some significant influence on shopper purchase behaviour. Empirical analysis indicates that retail atmospherics account for 34\% of shopper purchase behaviour and that design cues are the most significant predictor of shopper purchase decision followed by ambient cues. Social cues do not exert any influence on purchase decisions. A 'moderation' and 'mediation' analysis revealed that though design and ambient cues influence purchase decisions independently, the interaction effect on each other is not significant. Consequently, there is a need to understand why social factors do not play a role in purchase behaviour. More importantly, there is the need to identify and understand other factors that account for the balance of 66\% in shoppers' buying behaviour. Such a study might focus on factors such as pricing, sales promotion, loyalty programmes and other psycho-social factors which may work as key influencers in customers purchase decisions. For practical purposes, the focus should be on the design and ambient cues in the conceptualisation, development, and management of large retail stores.
\end{abstract}

JEL classification: M30, M300

Keywords: retail atmospherics, ambience, shopper behaviour, shopper purchase decision, retail store environment, nonverbal communication 


\section{INTRODUCTION}

\subsection{Background}

The primary focus of communication is on the how, why, and with what effects people communicate through spoken language and associated nonverbal messages (Association of Communication Administration, 1981). According to Lasswell (1948), one of the essential functions of communications is the surveillance of the environment and responding to stimuli inherent in such environment. Such responses could be either psychological, physiological or in some cases behavioural. Consequently, the environment where we find ourselves plays a significant role in the way humans interpret both verbal and nonverbal cues emanating from such environment. Communication has two central components: verbal and nonverbal. The verbal part refers to spoken words we use during communication while the nonverbal one often refers to communication that is produced by some means other than words (Knapp and Hall, 2002). Recently, there has been an exponential growth in interest and consequent research in the role of nonverbal behaviour in communication in relation to a broad range of behaviours (Buck and VanLear, 2002). Of great interest are atmospheric elements inherent in retail store environments and the role they play in the shopper purchase decisions.

Over the years, scholars and practitioners in the field of marketing and psychology have been interested in the reason why people buy and have made giant strides in understanding the key drivers of purchase decisions. The need for this study arose out of the shift in attention to the Nigerian market by major global retail chains, the increasing sophistication of the Nigerian shopper, and the limited resources available to satisfy human needs. Other factors include the advent of online retail stores like Jumia, Konga, Yudala, Kaymu and many others in Nigeria. With the malls came the promise of quality, convenience, after-sales service and total shopper satisfaction. These malls leverage on both verbal and nonverbal communication to achieve their business objectives. The structure and size of the shops, lighting, colours, merchandising, airconditioning, and music are examples of atmospheric cues utilised to communicate nonverbally to shoppers.

While vast financial resources are invested by the management of these malls in Nigeria, there is a need to drill further down to unearth the level of influence of these atmospheric cues on purchase behaviour, especially in the Nigerian retail space. Though the general perception is that they do exert some influence, there is a need to identify which atmospheric cues exert the most significant influence on customer purchase behaviour. A clear understanding of shopper purchase behaviour in response to the myriads of atmospheric cues that exist in modern trade outlets will be critical to customer satisfaction and loyalty. It is, therefore, imperative to understand the effectiveness of this shopper attraction and retention strategy.

Globally, some studies have been carried out on retail atmospherics and customer behaviour. However, only a few focus on emerging markets such as Nigeria and none has approached the subject from a broad perspective that incorporates the categorisation of store atmospherics by Baker et. al. (1986) and their influence on shopper purchase behaviour. Attempts within the Nigerian space to study atmospherics focused on 'store layout and customer loyalty' (Onuoha and Nnennaya, 2017); 'atmospherics and patronage in the banking sector' (Adiele and Nwaeke, 2015); and 'store atmosphere and impulse buying' (Ukpabi et al., 2015). Consequently, this paper is unique in its originality as it adopts a holistic approach to understanding retail atmospherics as it affects shopper purchase behaviour. The study promises to add to scholarly knowledge by dissecting the influence of atmospheric cues on purchase behaviour and isolating the atmospheric cues that exert the most significant influence on shopper purchase behaviour. 


\subsection{The Place of Retail Space in the Marketing Mix}

A crucial and vital component of the marketing mix is 'place' which is the point of interface between a business organisation with other elements of the marketing mix (product, price, and promotion) and the consumers. The centrality of 'place' is evident because the physical environment of retail outlets influences how customers feel (Baker et al., 2002). Place refers to the channels used to get an organisation's product to its clients. In response to competition and the need to elicit customer loyalty, 'place' has become an arena that attracts a high level of creativity and innovation in the marketing value chain. The overarching objective is to create the right environment for sales to thrive. An appropriate place strategy will result in making goods available to consumers at the right location and time.

Aside from developing the right product, deploying customer-friendly price and educating both existing and potential customers on the key benefits of the product, 'place' is gradually becoming a key component of all marketing strategies. Most manufacturers and service providers have long acknowledged the centrality of the business environment - be it a mall, a retail shop, a banking hall or the reception area of a multinational organisation - as playing a key role in creating the right stimulus to attract and retain desired customers. In malls, manufacturers and supplier of goods go the extra mile to assist in creating the right ambience using various atmospheric cues that will make for a positive shopping experience. This is because the products on display at competing stores are often perceived as similar - hence the need for differentiation, leveraging on the environment.

\subsection{Evolution of Retail Atmospherics as Nonverbal Communication}

One of the mixed blessings of human history is that humans increasingly live, work, and play in an artificial environment (Kotler, 1973). The physical retail environment has provided the setting for consumer engagement and has become the focus of retailers and brand owners (OgdenBarnes and Barclay, 2011). Fundamental advances in business processes include the recognition that people, in their purchase decision-making, respond to more than only a tangible product or service on offer (Kotler, 1973). Mulhern (1997) argues that retail business has experienced a shift in focus from traditional merchandising with its attendant attention to the marketing mix elements, to more active customer engagement and management through a more integrated approach. The emphasis, therefore, has now been placed on customer relationships, motivating and rewarding loyal customers and, at the same time, maintaining a cordial relationship with manufacturers.

Place design and management have been identified as an essential marketing tool in building and sustaining brand equity. Trade channels are seen as points of consumer contact and engagement. The business of selecting and managing retailers for a specific brand is taken seriously by manufacturers as it can lead to customer satisfaction. Dodds, Kent and Dhruv (1991) identify significant positive effects of store image on the perceived quality of merchandise. In some cases, the name of the retail outlet is a strong pointer to perceived quality, and this is why the quality of a given brand is seen differently depending on where it is on offer. Customer traffic may likely be greater in a store with a positive atmosphere than in one with a negative atmosphere. Also, such stores provide greater customer satisfaction which leads to good will, loyalty and also stimulates word of mouth recommendations (Rao and Monroe, 1989; Zeithaml, 1988).

With the traditional retail channels in Nigeria giving way to modern malls (Shoprite, Game, Spar, Mega Plaza, and others), there is an increasing desire among these modern trade channels to compete favourably with the aim of increasing their bottom line. This remarkable increase in competition within the modern trade channels, in turn, stimulates the need to devise ways of achieving differentiation in the retail offering (Morrison et al., 2011). Aside from offering good quality products in line with consumer demands, malls now consider other factors like shelf 
design, lighting, colour, merchandising, music, sampling as forms of nonverbal communication in their aim to create an optimal shopping environment.

Research has identified three primary sets of atmospheric cues utilised in many retail environments. These are design, ambient, and social factors (Baker, 1986).

Table 1

Classification of atmospheric cues

\begin{tabular}{|c|c|c|c|}
\hline \multicolumn{4}{|c|}{ COMPONENTS OF THE PHYSICAL STORE ENVIRONMENT } \\
\hline Ambient Factors & $\begin{array}{l}\text { Represented by background } \\
\text { conditions that exist below } \\
\text { the level of our immediate } \\
\text { awareness }\end{array}$ & $\begin{array}{l}\text { Air quality } \\
\text { - (Temperature/humidity } \\
\text { Noise (Level \& pitch) } \\
\text { Scent } \\
\text { Cleanliness }\end{array}$ & ulation/ventilation) \\
\hline Design Factors & $\begin{array}{l}\text { Represent stimuli that exist } \\
\text { at the forefront } \\
\text { of our awareness }\end{array}$ & $\begin{array}{l}\text { Aesthetics } \\
\text { - Architecture } \\
\text { - Colour / style } \\
\text { - Materials / décor } \\
\text { - Scale / shape } \\
\text { - Texture / pattern }\end{array}$ & $\begin{array}{l}\text { Functional } \\
\text { - Layout } \\
\text { - Comfort } \\
\text { - Shelf design } \\
\text { - Signage } \\
\text { - Accessories }\end{array}$ \\
\hline Social Factors & $\begin{array}{l}\text { Refer to people } \\
\text { in the environment }\end{array}$ & $\begin{array}{l}\text { Audience (Customers) } \\
\text { - Number } \\
\text { - Appearance } \\
\text { - Behaviour }\end{array}$ & $\begin{array}{l}\text { Service personnel } \\
\text { - Number } \\
\text { - Appearance } \\
\text { - Behaviour }\end{array}$ \\
\hline
\end{tabular}

Source: Baker et al. (1986)

\subsection{Emergence of Modern Trade in Nigeria}

It is obvious that the recession in Europe and North America at the dawn of the new millennium has led to a shift in attention towards the African market. The focus is largely on the Nigerian market probably because of the perceived large consumer population. Consequently, the Nigerian economy has witnessed an influx of foreign enterprises, multinationals, and mega retail chains which has led many economic analysts to predict a phenomenal growth in the Nigerian economy within the next five years. This was boosted by the rebasing of the economy in 2014, which resulted in Nigeria evolving to be the biggest economy in Africa (The Economist, 2014), even though the dwindling oil revenue and current recession have caused Nigeria to drop to the second position in 2016.

This trend has led to the entry into the Nigerian market of big names in the global retail industry such as Spar, Shoprite, Mr Price, Woolworths and Game with more on the way. These retail chains came with promises of convenience, quality assurance, and after-sales service. As shoppers get more health conscious and more sophisticated, the perception that products sold in these malls are healthier and offer better quality than those sold in the open markets increases. Observation has revealed that products that require storage in particular environmental conditions are seen lying under the hot sun in the traditional open markets as is evident in the popular Alaba, Idumota, Oke-Arin and Ojuwoye markets in Lagos. Today, shoppers view these practices as health risks and thus will queue for fresh bread from the oven at Shoprite rather than buy from roadside shops and open markets. 


\section{LITERATURE REVIEW}

\subsection{Introduction}

Based on the classical premise of environmental psychology, studies on customer purchase behaviours often take the position that a retail store environment arouses certain specific emotions in customers. Extant literature has shown that consumers respond not only to the core product on offer during their purchase decision-making process but also to the total product. An essential component of the total product is the place where the product is purchased. In particular cases, the location of purchase, or more appropriately the retail atmosphere exerts more influence on purchase decisions than the core product itself (Kotler, 1973). Consequently, there have been concerted efforts within the academia to study the extent of influence of retail atmosphere on consumer purchase behaviour. While some of these studies were approached from a holistic (all the environmental cues) standpoint (Kotler, 1973; Turley and Milliman 2000; Puccinelli et al., 2009; Kumar et al., 2010; Chen and Hsieh, 2011; Joshi and Kulkarni, 2012; Bohl, 2012; Grewal et al., 2014; Singh et al., 2014), others focus on specific atmospheric cues such as background music (Santos and Freire, 2013; Milliman, 1982), store space (Markin et al., 1976), crowding (Eroglu and Harrell, 1986; Hui and Bateson, 1991), music and lighting and social interaction (Baker et al., 1992).

In a study focusing on the Taiwanese market, Chen and Hsieh (2011) revealed that store atmospheric factors have a significant positive correlation with customer approach behaviours, design factors being the most significant among all factors. This confirms the views of Bitner (1992), who believes that shoppers tend to avoid unpleasant environments and approach those with the likelihood of making them happy. Consequently, by manipulating design and ambient factors, retail store operators can create a pleasant store atmosphere that can make for a more experiential and enjoyable shopping experience.

The use of music has been applied in traditional areas such as psychology, through the discipline of environmental psychology (Donovan and Rossiter, 1982). Music variations such as how fast or slow, type and popularity influence consumers' mood (Yalch and Spangenberg, 2000); time spent in shops (Kellaris and Altech, 1992; Kellaris and Kent, 1992), customer emotions (Mehrabian and Russell, 1974) and shopper purchase decisions (Santos and Freire, 2013). Smith and Curnow (1966) stated that time spent in a retail store and sales were adversely related to 'loud' music. Time spent in stores was significantly shorter when music was loud. Meanwhile, total sales were not influenced by music loudness. However, they noted an increase in sales per minute because customers were found to spend less time within the store (Smith and Curnow, 1966).

A clear understanding of customers' colour preferences will facilitate the creation, development, and communication of the store image. For most customers, different colours are associated with different meanings which are tied to their individual or communal culture. The Chinese associate white with death, unlike some other cultures that associate it with peace. Understanding attitudes towards colours and their interpretation beyond textual context can help add value to a retail store image.

Areni and Kim (1994) state that olfactory factors such as scent, freshness and tactile factors such as temperature help in creating a calming and friendly atmosphere in a retail store. These factors contribute to the store image by eliciting an aesthetically sensitive disposition, enhancing the store's merchandise quality, its clientele, and their comfort. Tactile factors such as temperature, smoothness of walls, furnishings, and floors also create an aesthetically sensitive atmosphere that can increase customers' value as a result of personal comfort. In the tropics, consumers often choose stores with air-conditioning because of the relatively humid climate. Availability of air cooling systems increases customer's exploratory tendencies within a retail store environment. 
These factors have the potential to change shoppers' emotional experiences such as anxiety, lack of interest, foul mood and uneasiness in a public place (Grossbart et al., 1990).

Design cues like the layout, shelf design, signage, décor can create an attractive and unique environment that appeals to people by signalling a pleasant experience. Customers can develop positive associations of trust, value, quality of goods and services, price, warranty and guarantee, and other factors, as they come across visuals such as signage, window dressing, logo, and others, based on past shopping experiences (Kumar et al., 2010). Graphic materials used throughout the retail environment can act as a link between the merchandise on display and the target market. In a study carried out in Port Harcourt, Nigeria, Ukpabi et al. (2015) confirmed that store interior, layout, and display all had a positive correlation with impulse buying.

Crowding in the context of the retail environment consist of both human and spatial crowding (Eroglu et al. 2005) and is calculated based on the specific number of shoppers within a retail store environment at a particular time. Crowding can result in some discomfort among customers depending on their level of tolerance and the number of shelves, furnishing, and inventory that might impinge on smooth navigation within the store area. In the case of excessive crowding, customers find it difficult to move around the store, thereby blocking their perceived shopping goal (Grossbart et al., 1990).

\subsection{Models of Shopper Behaviour}

The notion that store atmospherics exert some influence on consumer behaviour was first introduced to marketing research by Kotler (1973). However, most current research on retail atmospherics leverages, to a large extent, on the Mehrabian-Russell model, which is at the core of a study area referred to as 'environmental psychology' and was first applied to retail settings by Donovan and Rossiter (1982). The field of environmental psychology is concerned with two broad segments: the direct impact of physical stimuli on human emotions and the effect of the physical stimuli on a variety of behaviours, such as work performance or social interaction (Mehrabian and Russell, 1974).

Mehrabian and Russell (1974), in developing a framework for analysing the effects of environment on humans, emphasised the role of nonverbal responses to environmental factors as a major determinant of human behaviour. According to them, the retail store environment contains various stimuli that might be perceived by the customer's senses.

Figure 1

Mehrabian and Russell's SOR framework

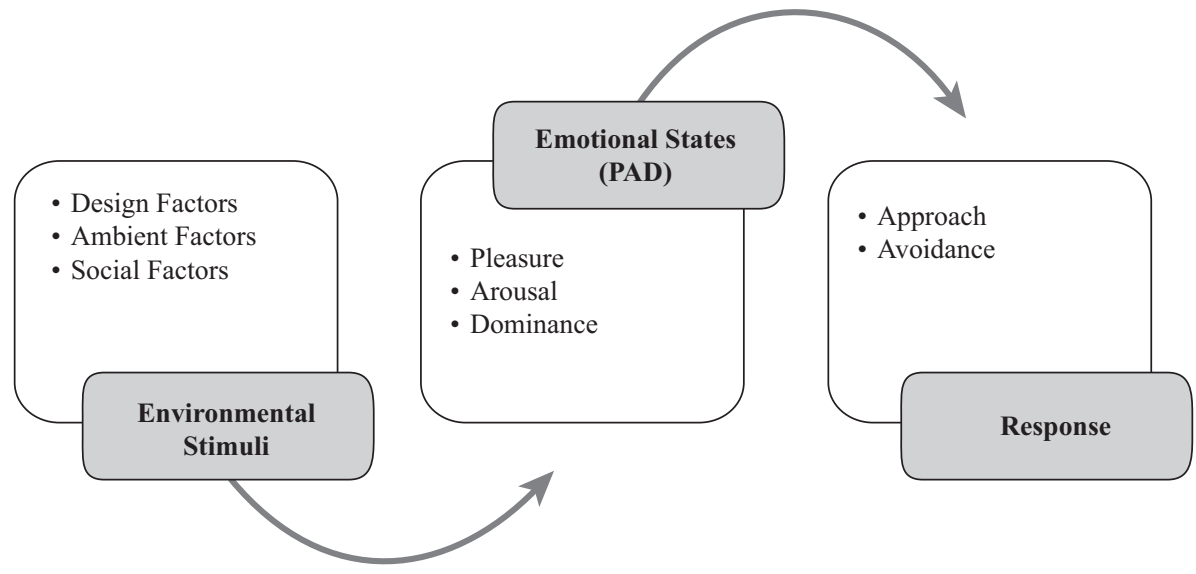

Source: Adapted from Mehrabian and Russell (1984)

The framework in Figure 1 above shows that people react to their environment along at least three dimensions: Pleasure, Arousal, and Dominance (PAD). The last section of the 
Mehrabian-Russell framework is a list of possible behavioural reactions to the environment. Even though some shopping behaviours can be affected in different ways by environmental factors, Mehrabian and Russell (1974) classify the effects along the line of approach or avoidance. Consequently, retail environments could be constructed or designed to encourage shoppers to approach a shop or discourage them from entering. Thus, within the retail store environment, it is confirmed that stimuli that elicit positive emotional responses almost always lead to approach behaviours, whereas those that elicit negative emotional responses result in avoidance (de Farias et al., 2014).

\section{METHODS AND PROCEDURE}

\subsection{Research Design}

Based on the Mehrabian-Russell S-O-R framework, this study sought to create an understanding of how retail atmospherics influence customers' purchase behaviour given the shift from shopping in traditional shops to malls in Lagos, Nigeria. The research design is shown in Figure 2 below.

\section{Figure 2}

Framework for research methodology

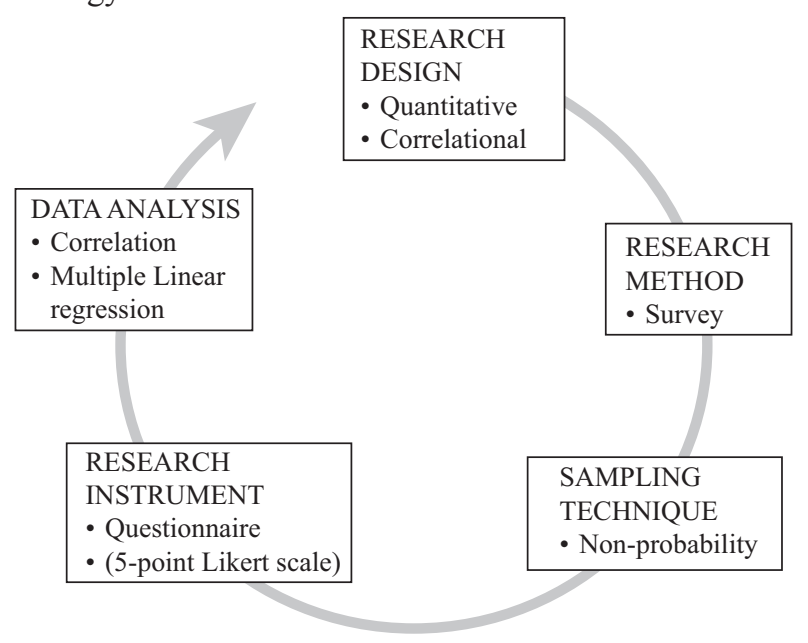

Source: authors

\subsection{Research questions}

A clear understanding of shopper purchase behaviour in response to the myriads of atmospheric cues that exist in modern trade outlets (malls) is crucial to customer satisfaction and loyalty. An enormous amount of financial and material resources is always spent on creating the 'right' ambience and an environment that promises to impact positively on shoppers' purchase decisions. It is, therefore, imperative to understand the effectiveness of this shopper attraction and retention strategy. The key research questions, therefore, include:

1. What atmospheric cues are mostly utilised at shopping malls?

2. In what way does an atmospheric cue relate with shopper purchase behaviour?

3. Which category of atmospheric cues significantly predicts a purchase decision?

4. What form of relationship exists between predictors of purchase behaviour? 


\subsection{Population, Questionnaire Design and Sampling Plan}

The population of study refers to customers, shoppers, and individuals of varied socioeconomic classes who visit shopping malls in Lagos, the most populous city in Nigeria, for the purpose of making a purchase. Leveraging on a pilot study conducted by observation and counting of shoppers at four major malls, the mean daily population of 1,057 is arrived at. This population was calculated from a weekday average of 800 visitors (Monday to Friday) and a weekend average (Saturday and Sunday) of 1,200 shoppers. Using a sample size calculator with a confidence interval of 5.0, a 95\% confidence level, a standard deviation of .5 and a population of 1,057 customers, a sample of 283 respondents was drawn. A non-probability sampling technique was adopted as respondents were selected based on accessibility.

The questionnaire was designed to reflect and address the key independent and dependent variables identified within the subject. These are arranged in sections, taking into account the different categories of atmospheric cues and purchase behaviour. Section A contains questions that address the key elements of the independent variables (ambient, design and social), applying Baker's (1986) classification of atmospheric elements. Section B focuses on questions that address the dependent variable (shopper purchase behaviour). All questions applied the 5-point Likert scale (Strongly Disagree $=1$, Disagree $=2$, Undecided $=3$, Agree $=4$ and Strongly Agree $=5$ ) .

A pilot sample of 100 respondents was used, and a reliability analysis check using Cronbach Alpha was carried out on the questionnaire questions in the three categories of atmospheric cues (design, ambient, and social) and purchase behaviour.

Table 2

Reliability analysis check for questionnaire questions

\begin{tabular}{|c|c|c|}
\hline \multicolumn{3}{|c|}{ Questionnaire Reliability Analysis Check } \\
\hline Cues & Cronbach Alpha & Range of item correlations \\
\hline Design Cue & .67 & $.38 / .46$ \\
\hline Ambient Cue & .66 & $.33 / .44$ \\
\hline Social Cue & .49 & $.20 / .39$ \\
\hline Retail atmospherics (Composite scale) & .75 & $.10 / .55$ \\
\hline Purchase Behaviour & .61 & $.23 / .44$ \\
\hline
\end{tabular}

Note: The low Cronbach alpha value for Social cue is accepted in consideration of the total mean values.

Source: authors using Cronbach Alpha

\section{RESULTS}

This study leverages on Baker's (1986) broad classification of atmospheric cues in the retail environment. The research instrument was administered to respondents to unearth the relationship between atmospheric cues and purchase behaviour. Answers to all questions as contained in the questionnaires were coded and then analysed using statistical applications (SPSS and Amos). Each category of the independent variables (Design, Ambient, and Social) was measured against purchase behaviour. Finally, the independent variables were tested for moderation and mediation. The results obtained indicate that $51 \%$ of respondents have been buying from the selected malls for upward of five years (see Table 3 below). 
Table 3

Length of time as customer

\begin{tabular}{|c|c|c|c|c|c|}
\hline \multicolumn{6}{|c|}{ Number of Years as a Customer } \\
\hline & & Frequency & Percent & Valid Percent & Cumulative Percent \\
\hline \multirow{5}{*}{ Valid } & Less than a month & 34 & 12.0 & 12.1 & 12.1 \\
\hline & Up to 6 months & 38 & 13.4 & 13.5 & 25.5 \\
\hline & Up to a year & 65 & 22.9 & 23.0 & 48.6 \\
\hline & Up to 5 years & 145 & 51.1 & 51.4 & 100.0 \\
\hline & Total & 282 & 99.3 & 100.0 & \\
\hline Missing & System & 2 & .7 & & \\
\hline Total & & 284 & 100.0 & & \\
\hline
\end{tabular}

Source: authors using SPSS

This is an indication that these malls enjoy a high level of loyalty from their patrons. Those shoppers who have visited the mall for less than a month represent just $12 \%$ of the total shoppers at the mall.

\section{Frequency of visit}

Table 4

Frequency of visits

\begin{tabular}{|c|c|c|c|c|c|}
\hline \multicolumn{6}{|c|}{ Frequency of Visit } \\
\hline & & Frequency & Percent & Valid Percent & Cumulative Percent \\
\hline \multirow{6}{*}{ Valid } & Once a day & 44 & 15.5 & 15.6 & 15.6 \\
\hline & Once in 2 days & 33 & 11.6 & 11.7 & 27.3 \\
\hline & Once in a week & 89 & 31.3 & 31.6 & 58.9 \\
\hline & Twice a month & 57 & 20.1 & 20.2 & 79.1 \\
\hline & Once in a month & 59 & 20.8 & 20.9 & 100.0 \\
\hline & Total & 282 & 99.3 & 100.0 & \\
\hline Missing & System & 2 & .7 & & \\
\hline Total & & 284 & 100.0 & & \\
\hline
\end{tabular}

Source: authors using SPSS

The result here shows that $32 \%$ of the shoppers visit the mall at least once in a week. This, to a large extent, supports the notion that most families shop weekly for household items. The result also supports the high percentage of loyal customers seen in the result from general question number two above.

\section{Key Atmospheric Cues in Retail Space}

A frequency count of the positive responses (strongly agree and agree alone) from respondents while discounting the negative responses (strongly disagree, disagree and undecided) shows that the atmospheric cue most important to shoppers is the location (a design cue) followed by lighting (an ambient cue). Queues are the least attractive to most customers. 
Table 5

Key atmospheric cues

\begin{tabular}{|c|c|c|c|}
\hline \multicolumn{4}{|c|}{ Key Atmospheric Cues in Retail Space } \\
\hline S/NO & Categories & Variables & Percentage \\
\hline 1 & \multirow{5}{*}{ Design Factors } & Location & 87.4 \\
\hline 2 & & General structure & 80.3 \\
\hline 3 & & Shelves & 80.6 \\
\hline 4 & & Ease of browsing & 73.5 \\
\hline 5 & & Product arrangement & 84.1 \\
\hline 6 & \multirow{6}{*}{ Ambient Factors } & Colour & 70.8 \\
\hline 7 & & Lighting & 86.7 \\
\hline 8 & & Scent / fragrance & 61.6 \\
\hline 9 & & Sound & 66.9 \\
\hline 10 & & Music & 54.9 \\
\hline 11 & & Temperature & 66.9 \\
\hline 12 & \multirow{6}{*}{ Social Factors } & Product demo & 59.5 \\
\hline 13 & & Queues & 36.6 \\
\hline 14 & & Crowding & 37.1 \\
\hline 15 & & Noise & 41.3 \\
\hline 16 & & Staff & 78.2 \\
\hline 17 & & Mall attendants & 48.2 \\
\hline
\end{tabular}

Source: authors using SPSS

However, using the mean values of all data from respondents which link the atmospheric variables to the purchase behaviour variables, it was observed that ambient cues account for a higher proportion of atmospheric cues deployed and utilised at the malls.

Table 6

Mean value of key atmospherics

\begin{tabular}{|c|c|c|c|}
\hline \multicolumn{4}{|c|}{ Mean Value of Key Atmospherics } \\
\hline Atmospheric Cue & Mean & Standard Deviation & Ranking \\
\hline Design & 19.31 & 2.98 & 2 \\
\hline Ambient & 21.90 & 3.50 & 1 \\
\hline Social & 18.99 & 3.45 & 3 \\
\hline
\end{tabular}

Source: authors using SPSS

Using statistical tools and based on the average values, ambient cue (21.90) is deployed more and attracts more attention from the management of malls compared to other cues: design cue (19.31) and social cue (18.99). 


\section{Relationship Between Retail Atmospherics and Purchase Behaviour}

Table 7

Correlation between atmospherics and purchase behaviour

\begin{tabular}{|c|c|c|c|}
\hline \multicolumn{4}{|c|}{ Correlation Between Atmospherics and Purchase Behaviour } \\
\hline & & Atmospheric Cue & Purchase Behaviour \\
\hline \multirow{3}{*}{ Atmospheric Cue } & Pearson Correlation & 1 & $.335^{* *}$ \\
\hline & Sig. (2-tailed) & & .000 \\
\hline & $\mathrm{N}$ & 282 & 282 \\
\hline \multirow{3}{*}{ Purchase Behaviour } & Pearson Correlation & $.335^{* *}$ & 1 \\
\hline & Sig. (2-tailed) & .000 & \\
\hline & $\mathrm{N}$ & 282 & 284 \\
\hline
\end{tabular}

\begin{tabular}{lcc} 
& Purchase Behaviour & Significance \\
\hline Atmospheric Cue & $.34 * *$ & $\mathrm{P}<.01$ \\
$\mathrm{~N}(282)$ & & \\
$* * \mathrm{P}<01$ at 2 -tailed & &
\end{tabular}

$* * \mathrm{P}<.01$ at 2 -tailed

Source: authors using SPSS

The table above shows that there is a positive correlation between the atmospheric cues at the malls and customers' purchase behaviour since correlation is significant at the 0.01 level with $\mathrm{P}<.01$. The result above confirms that purchase behaviour in malls is positively influenced by atmospherics.

\section{Key Predictor of Purchase Behaviour}

Table 8

Key predictor of purchase behaviour

\begin{tabular}{|c|c|c|c|c|c|c|c|}
\hline \multicolumn{8}{|c|}{ Coefficients $^{\mathrm{a}}$} \\
\hline & \multirow{2}{*}{ Model } & \multicolumn{2}{|c|}{ Unstandardised Coefficients } & $\begin{array}{c}\text { Standardised } \\
\text { Coefficients }\end{array}$ & \multirow[t]{2}{*}{$\mathbf{t}$} & \multirow{2}{*}{ Sig. } & $\begin{array}{c}\text { Collinearity } \\
\text { Statistics }\end{array}$ \\
\hline & & B & Std. Error & Beta & & & Tolerance \\
\hline \multirow{4}{*}{1} & (Constant) & 10.982 & 1.345 & & 8.165 & .000 & \\
\hline & Design cue & .278 & .067 & .277 & 4.167 & .000 & .700 \\
\hline & Ambient cue & .113 & .057 & .132 & 1.973 & .049 & .690 \\
\hline & Social cue & .019 & .051 & .021 & .364 & .716 & .898 \\
\hline
\end{tabular}

\begin{tabular}{|c|c|c|c|}
\hline & B & SEB & $\beta$ \\
\hline Constant & 10.98 & 1.35 & \\
\hline Design cues & .28 & .07 & $.28 * *$ \\
\hline Ambient cues & .11 & .06 & $.13^{*}$ \\
\hline Social cues & .02 & .05 & .71 \\
\hline
\end{tabular}

$* * \mathrm{P}<.01 * \mathrm{P}<.05$ Dependent variable Purchase decision

Source: authors using SPSS 


$$
Y=a+B_{1} x_{1}+B_{2} X_{2}
$$

The result above shows that for every one unit increase in design cues, a shopper's purchase decision increases by a value of .28 of a standard deviation at $\mathrm{P}<.01$. This value confirms that design cues are significant positive predictors of shopper purchase behaviour, and proves that the positive prediction of purchase behaviour by design cues does not arise out of error. Furthermore, the results also show that for every one unit increase in ambient cues, a shopper's purchase decision increases by a value of .13 of a standard deviation at $\mathrm{P}<.05$. Thus, the ambient cue is a significant predictor of shopper purchase decisions. With a value of $\mathrm{P}>.05$, social cues do not predict a purchase decision.

\section{Test for Moderation Effect of Key Predictors of Purchase Behaviour}

A test for moderation between ambient and design cues showed non-significance and thus does not tell any different story. However, design and ambience cues independently continue to exhibit a significant relationship with purchase behaviour. Consequently, the variables are not moderators by themselves for purchase behaviour (see table below).

Table 9

Test for moderation

\begin{tabular}{|c|c|c|c|c|c|c|}
\hline \multicolumn{7}{|c|}{ Tests of Between-Subjects Effects } \\
\hline \multicolumn{7}{|c|}{ Dependent Variable: Purchase Behaviour } \\
\hline Source & Type III Sum of Squares & df & Mean Square & F & Sig. & Partial Eta Squared \\
\hline Corrected Model & $275.705^{\mathrm{a}}$ & 3 & 91.902 & 11.307 & .000 & .108 \\
\hline Intercept & 89613.371 & 1 & 89613.371 & 11025.193 & .000 & .975 \\
\hline Design & 98.506 & 1 & 98.506 & 12.119 & .001 & .041 \\
\hline Ambient & 107.850 & 1 & 107.850 & 13.269 & .000 & .045 \\
\hline Design * Ambient & 7.483 & 1 & 7.483 & .921 & .338 & .003 \\
\hline Error & 2275.855 & 280 & 8.128 & & & \\
\hline Total & 107253.000 & 284 & & & & \\
\hline Corrected Total & 2551.560 & 283 & & & & \\
\hline
\end{tabular}

a. $\quad$ R Squared $=.108$ (Adjusted R Squared $=.098$ )

b. The design and ambient data were split into two by the mean values to achieve the categories

Source: authors using SPSS

Testing for the Mediation Effect of Ambience

A test for the mediation effect of ambient cues on design cues also showed non-significance even though they independently exhibit a significant relationship with purchase behaviour. Since the previous statistical analysis indicates that the design cue is the most important predictor of purchase behaviour, a test was carried out to investigate the mediating effect of ambience on design cues. The key assumptions for Mediation is that the mediator (Ambience) must have a significant relationship with the dependent variable (Purchase Behaviour) and the predictor (Design). However, in the results below, the mediator has a significant association with the independent variable, but no relationship with the dependent variable. Thus, the assumptions for mediation are violated. 
Figure 3

Framework for mediation

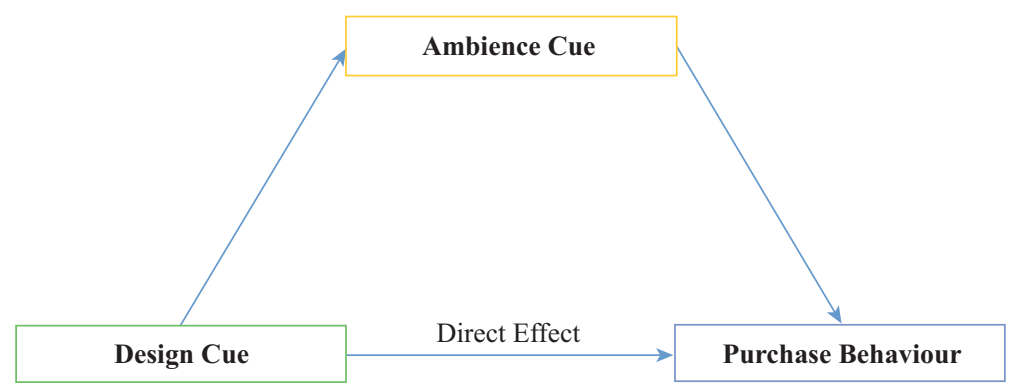

Source: authors

Before Mediation, the direct effect of design on purchase behaviour is significant, $\mathrm{P}<.001$. However, the study indicated that after the Mediation effect of ambience is tested, the direct influence of design drops from .32 to .28 , and is insignificant, but the indirect effect of the mediator (ambient) is violated as ambience did not show significant relationships with purchase behaviour (see mediation analysis below).

Table 10

Test for Mediation - before mediation

\begin{tabular}{|c|c|c|c|c|c|c|c|}
\hline & & & Estimate & S.E. & C.R. & $\mathbf{P}$ & Label \\
\hline pb & $<---$ & $\mathrm{d}$ & .323 & .096 & 3.376 & $* * *$ & par_1 \\
\hline
\end{tabular}

Source: authors using Amos

Table 11

Test for Mediation - after mediation

\begin{tabular}{ccc|c|c|c|c} 
& & & Estimate & S.E & C.R & P \\
\hline AM & $<---$ & d & .474 & .119 & 3.994 & $* * *$ \\
\hline pb & $<---$ & d & .281 & .191 & 1.473 & .141 \\
\hline pb & $<---$ & AM & -.022 & .329 & -.066 & .947
\end{tabular}

Source: authors using Amos

Figure 4

Effects before and after mediation

Before Mediation

Source: authors using Amos 


\section{FINDINGS AND DISCUSSION}

\subsection{Findings}

By using relevant statistics, this study confirms that there is a positive relationship between retail atmospherics and customer purchase behaviour with the relationship at $34 \%$. The study also revealed that design factors and ambient factors significantly influence purchase behaviour with design factors being the highest predictor of purchase behaviour, while social cues do not exert significant influence on customers' purchase decisions. Consequently, the results can be summarised as follows:

Table 12

Summary of outcomes Outcome 1 behaviour variables revealed that ambient factors at 21.9 account for a higher proportion of the cues utilised at the malls.

There is a positive correlation between retail atmospherics and customer purchase behaviour
with atmospherics accounting for $34 \%$ of a shopper's purchase decision. This is an indication
that the correlation is significant at the 0.01 level with $\mathrm{P}<.01$.

Statistical analysis shows that for every one unit increase in design cues, a shopper's purchase decision increases by a value of .28 of a standard deviation at $\mathrm{P}<.01$. On the other hand, for every one unit increase in ambience, a shopper's purchase decision increases by a value of .13 of a standard deviation at $\mathrm{P}<.05$. Thus, design cues with an associated value of $\mathrm{P}<.01$

Outcome 3 are significant and their positive prediction of purchase behaviour did not arise out of error. Hence, design cues are the most significant predictor of purchase behaviour. Though there exists a positive relationship between the ambient cue and purchase behaviour, it is not as significant as design cues. With a value of $\mathrm{P}>.05$, social cues do not predict a purchase decision. Thus, Purchase decision $=10.98+.28$ Design +.13 Ambient

By relying on statistical tools, the study shows that the interactions between design and ambient cues are not significant! Thus we may conclude that the variables do not have any

Outcome 4 moderation on each other. Though both variables independently are significant predictors of purchase behaviour, there is no evidence of an interaction effect of both variables on purchase behaviour. The study also indicated that there is no mediation effect - partial or full - of the ambient cue on the relationship between design cue and purchase behaviour.

Source: authors

\subsection{Discussion}

Consumers appear to perceive retail environments in an ambient, holistic manner, such that they have direct and provider-mediated effects on outcomes (Morin et al., 2007). According to Chen and Hsieh (2011), all store atmospheric factors, except for environmental crowding, have a significant impact on customer approach behaviours in large supermarkets in Taiwan. This study can, therefore, be seen as a confirmatory study of the position of Chen and Hsieh (2011). In-depth analysis of data collected from respondents shows that both design and ambient factors play a significant role in customer purchase behaviour. By ranking the outcomes according to their level of significance, design cues came out as the most significant predictor of purchase behaviour followed by ambient cues. A further test of mediation and moderation on design and ambient cues shows that while both independently influence purchase behaviour, the interaction effect of both variables on purchase behaviour is not significant. Thus, there is neither a moderation effect nor a mediation effect on each other.

This result is a clear pointer to the level of growth and development of the formal retail sector in Nigeria. The emergence of this sector as exemplified by large shopping malls is still a new 
phenomenon as a majority of the populace still patronise the informal, open market for shopping. Consequently, the design aspects of retail stores have been seen as an ideal convergence of artistic ideas, instinct, and business in a planned and profitable manner (Kumar et al., 2010). Customers find the general layout of the malls, the positioning of shelves, signage, and arrangement of products on the shelves very attractive. Thus, there is a need for retailers to consistently create or identify new locations where space, cost, and flexibility are designed in such a way that they effectively communicate brand value and attract consumers (Din, 2000). The general layout of a retail store, therefore, can communicate value by increasing comfort, product quality, price, the size of inventory and efficiency in browsing through the shelves. These shoppers are willing to pay more for a product seen in a big shopping mall than in traffic or open markets in Lagos. One can assert that favourable environment facilitates the development of positive associations of trust, value, and quality.

The effect of ambient cues on shopper behaviour supports man's innate attraction to a relaxed environment. The combination of fragrance, lighting, air-conditioning, the colour of painting creates a relaxed and welcoming atmosphere at malls. Areni and Kim (1994) were able to relate in-store illumination, shopper's cognition, the perception of value and consumption patterns to consumers' arousal and vision. At variance with the results of this study, earlier studies on retail atmospherics tend to support the view that crowding has a negative influence on consumer evaluations of the shopping experience (Turley and Milliman, 2000). Crowding has a negative impact on browsing and comparison shopping, some purchases, postponed shopping, going to another shop (Grossbart et al., 1990) and quality perceptions (Wakefield and Blodgett, 2002) seen in Turley and Milliman (2000). This view is supported by Chen and Hsieh (2011) and Graa et al. (2014). Conversely, Joshi and Kulkarni (2012) and Singh et al. (2014) arrived at the conclusion that social cues do indeed exert a positive influence on shopper behaviour. However, the results here indicate that malls represent a significant improvement with regard to crowding when compared with the huge crowds that characterise the open markets in Nigeria. Hence, crowding, a social cue, does not have a significant influence on shopper purchase behaviour.

The non-significance of social cues on shopper purchase behaviour can be attributed to the fact that unlike clubs and bars, most malls in Nigeria are not designed with socialisation in mind. Again, because they are located in the major cities as against rural areas, the probability of meeting an acquaintance within the mall is little. For most shoppers, a visit to the mall is primarily to shop and not to socialise. Through direct observation, it was noticed that most shoppers were in a hurry to leave after shopping and had little or no time for socialisation.

Testing for mediation and moderation between design and ambient cues reveals some fascinating facts. The results for both tests turned out to be insignificant. The non-significance is not surprising in an environment where the primary touch point for shoppers are the open markets and neighbourhood shops where both design and ambient factors are relegated to the background. The emergence of modern trade (malls) in Nigeria is a recent phenomenon, and it will take a while for shoppers to get used to the positive atmosphere promised by these malls and see them as standard in their shopping experience.

In summary, even though design and ambient cues significantly influence shopper behaviour, customers will still buy in unsophisticated ambient and design.

\section{CONCLUSION}

This research has further proven the relevance of the Stimulus - Organism - Response (SOR) model of Mehrabian and Russell in shopper purchase behaviour. The study revealed that storeinduced pleasure is robust enough to attract customers to a retail environment. Thus, people will 
likely visit those shops that elicit pleasurable experience. Using the research objectives as spelt out for this study, the study concludes as follows:

- Malls deploy a variety of atmospheric elements in their bid towards attracting and retaining customers, but the most obvious are the ambient factors.

- There is a positive correlation between retail atmospherics and customer purchase behaviour with atmospherics accounting for $34 \%$.

- Though ambient cues were found to influence buying behaviour, the most significant predictor of purchase behaviour is designed cues. Social cues do not play any significant role in customer purchase behaviour. Furthermore, there is no evidence of a moderating and mediating effect between the predictors of purchase behaviour. While design cues and ambient cues independently influence shopper purchase behaviour, there is no moderation or mediating effect of ambient cues on design cues.

There is a need to understand why social factors do not play a role in purchase behaviour and explore ways to incorporate socialisation in the purchase decision process of customers. Focus at this stage of development in modern trade should be on achieving conversion from shopping in the open markets and neighbourhood stores to large malls. This is because of the no moderation and mediation between the significant predictors of purchase behaviour. More importantly, there is the need to identify and understand other factors that account for the balance of $66 \%$ since this study has shown that atmospherics account for just 34\% of shoppers' purchase behaviour. Such research might focus on factors such as pricing, sales promotion, loyalty programmes and other psycho-social factors which may work as key influencers in customers purchase decisions.

The Nigerian retailer needs to consistently create or identify new locations where space, cost, and flexibility are designed in such a way that they effectively communicate brand value and attract consumers (Din, 2000). This is because the general layout of a retail store can communicate value by increasing comfort, product quality, price, the size of inventory and efficiency in browsing through the shelves. The effect of ambient cues on shopper behaviour supports man's innate attraction to a relaxed environment. The combination of lighting, air-conditioning and the colour of painting creates a relaxed and welcoming atmosphere and facilitates a smooth and stress-free shopping experience.

\section{References}

Adiele, K.C. and Nwaeke, L.I. (2015) 'Effect of atmospherics on bank patronage behaviour: Lessons from Nigeria retail banks', Review of Communication and Media Studies, Vol. 1 No. 2, pp. 153-163.

Areni, C.S. and Kim, D. (1994) 'The influence of in-store lighting on consumers' examination of merchandise in a wine store', International Journal of Research in Marketing, Vol. 11, pp. 117-125.

Association of Communication Administration (1981) Careers in communication arts and science. Falls Church, VA.

Baker, J. (1986) 'The role of environment in marketing services: The consumer perspective', in: Czpeil, J.A., Congram, C. and Shanahan, J. (Eds.), The services marketing challenge: Integrated for competitive advantage, American Marketing Association, Chicago, pp. 79-84.

Baker, J., Levy, M. and Grewal, D. (1992) 'An experimental approach to making retail store environmental decisions', Journal of Retailing, Vol. 68 No. 4, pp. 445-461.

Baker, J.A., Parasuraman, A., Grewal, D. and Voss, G.B. (2002) 'The influence of multiple store environment cues on perceived merchandise value and patronage intentions', Journal of Marketing, Vol. 66 No. 2, pp. 120-141.

Bitner, M.J. (1992) 'Servicescapes: The impact of physical surroundings on customers and employees', Journal of Marketing, Vol. 56, pp. 57-71.

Bohl, P. (2012) 'The effects of store atmosphere on shopping behaviour - A literature review', Corvinus Marketing Tanulmanyok, Vol. 1, pp. 1-23.

Buck, R. and VanLear, A.C. (2002) 'Verbal and nonverbal communications: Distinguishing symbolic, spontaneous, and pseudo-spontaneous nonverbal behavior', Journal of Communications, pp. 522-541.

Chen, H.-S. and Hsieh, T. (2011) 'The effect of atmosphere on customer perceptions and customer behaviour responses in chain store supermarkets', African Journal of Business Management (Academic Journals), Vol. 5 No. 24. 
Din, R. (2000) New Retail. London: Conran Octopus.

Dodds, W.B, Monroe, K.B. and Grewal, D. (1991) 'Effects of price, brand, and store information on buyers' product evaluation', Journal of Marketing Research, Vol. 28, pp. 307-319.

Donovan, R.J. and Rossiter, J.R. (1982) 'Store Atmosphere: An environmental psychology approach', Journal of Retailing, Vol. 58, pp. 34-57.

Eroglu, S.A., Machleit, K.A. and Chebat, J. (2005) 'The Interaction of Retail Density and Music Tempo: Effects on Shopper Responses’, Psychology \& Marketing, Vol. 22 No. 7, pp. 577-589. http://dx.doi.org/10.1002/ mar.20074.

Eroglu, S.A. and Harrell, G.D. (1986) 'Retail crowding: Theoretical and strategic implications', Journal of Retailing, Vol. 62 (Winter), pp. 346-363.

de Farias, S.A., Aguiar, E.C. and Melo, F.V. (2014) 'Store atmospherics and experiential marketing: A conceptual framework and research propositions for an extraordinary customer experience', International Business Research, Vol. 7 No. 2, pp. 87-99.

Grewal, D., Roggeveen, A.L., Puccinelli, N.M. and Spence, C. (2014) 'Retail atmospherics and in-store nonverbal cues: An introduction', Psychology and Marketing (Wiley Periodicals), Vol. 31 No. 7, pp. 469-471. doi:10.1002/mar.20708.

Grossbart, S., Hampton, R., Rammohan, B. and Lapidus, R.S. (1990) 'Environmental dispositions and customer response to store atmospherics', Journal of Business Research, Vol. 21, pp. 225-241.

Hui, M.J. and Bateson, J.G. (1991) 'Perceived control and the effects of crowding and consumer choice on the service encounter', Journal of Consumer Research, Vol. 18 (September), pp. 174-184.

Joshi, J.V. and Kulkarni, V.R. (2012) 'A factorial study of impact of store atmospherics in organized retail chain stores on consumers shopping experience', Management Insight. Vol. VIII No. 2, pp. 89-98.

Kellaris, J.J. and Altsech, M.B. (1992) 'The experience of time as a function of musical loudness and gender listener', Advances in Consumer Research, pp. 725-729.

Kellaris, J.J. and Kent, R. (1992) 'The influence of music on consumers' temporal perceptions: Does time fly when you're having fun?' Journal of Consumer Psychology, Vol. 1, pp. 365-376.

Knapp, M.L. and Hall, J.A. (2002) Nonverbal communication in human interaction (5th). Wadsworth: Thomson Learning, Inc.

Kotler, P. (1973) 'Atmospherics as a marketing tool', Journal of Retailing, Vol. 49 No. 4, pp. 48-64.

Kumar, I., Garg, R. and Rahman, Z. (2010) 'Influence of retail atmospherics on consumer value in an emerging market condition', Great Lakes Herald, Vol. 4 No. 1, pp. 1-13.

Lasswell, H.D. (1948) 'The structure and function of communication in society', in: Byon, L. (Ed), The communication of ideas, Harper \& Row, New York.

Markin, R.J., Lullis, C.M. and Narayana, C.L. (1976) 'Social-psychological significance of store space', Journal of Retailing, Vol. 52 (Spring), pp. 43-55.

Meenakumari, S. (2013) 'Store interior atmospherics and impulsive buying behaviour', Journal of Management, Vol. 1 No. 1, pp. 87-92.

Mehrabian, A. and Russell, J.A. (1974) An approach to environmental psychology. Cambridge, Massachusetts: MIT Press.

Milliman, R.E. (1982) 'Using Background Music to Affect the Behavior of Supermarket Shoppers', Journal of Marketing, Vol. 46, pp. 86-91.

Morin, S., Dube, L. and Chebat, J.-C. (2007) 'The role of pleasant music in servicescapes: A test of the dual of environmental perception', Journal of Retailing, Vol. 83 No. 1, pp. 115-130.

Morrison, M., Gan, S., Dubelaar, C. and Oppewal, H. (2011) 'In-store music and aroma influences on shopper behaviour and satisfaction', Journal of Business Research, Vol. 64, pp. 558-564.

Mulhern, F.J. (1997) 'Retail marketing: From distribution to integration', International Journal of Research in Marketing, Vol. 14 No. 2, pp. 439-450.

Ogden-Barnes, S. and Barclay, D. (2011) Store sense: Reclaiming the four walls with sensory engagement. Retrieved 02.02.2015 from http:/www.biaa.com.au/resources/Library/store-sense.pdf.

Onuoha, O.A. and Nnennaya, D. (2017) 'Store layout and customer loyalty of supermarkets in Port Harcourt, Nigeria’, International Journal of Managerial Studies and Research, Vol. 5 No. 3, pp. 34-39. doi:10.20431/2349-0349.0503005.

Puccinelli, N.M., Goodstein, R. C., Grewal, D., Price, R., Raghubir, P. and Stewart, D. (2009) 'Customer experience management in retailing: Understanding the buying process', Journal of Retailing, Vol. 85, pp. 15-30.

Santos, E. B. and Freire, O.B. $(2013,9)$ 'The influence of music on consumer purchase behaviour in retail environment', Independent Journal of Management and Production, Vol. 4 No. 2, pp. 537-548. doi:10.14807/ ijmp.v4i2.111

Singh, P., Katiyar, N. and Verma, G. (2014) 'Retail shoppability: The impact of store atmospherics and store layout on consumer buying patterns', International Journal of Scientific and Technology Research, Vol. 3 No. 8 , pp. 15-23. 
Smith, P.C. and Curnow, R. (1966) 'Arousal hypotheses and the effects of music on purchase behaviour', Journal of Applied Psychology, Vol. 50 No. 3, pp. 255-256.

The Economist (12.04.2014) Africa's new number one. Retrieved from: http:/www.economist.com/news/ leaders/21600685-nigerias-suddenly-supersized-economy-indeed-wonder-so-are-its-still-huge.

Turley, L.W. and Milliman, R.E. (2000) 'Atmospheric Effects on Shopping Behaviour: A Review of the Experimental Evidence', Journal of Business Research, Vol. 49 No. 2, pp. 193-211.

Ukpabi, D.C., Enyindah, C.W., Gwere, P.J. and Ejire, S. (2015) 'Store atmosphere and impulse buying: An empirical study of shoppers in Port Harcourt', The International Academic Conference for Sub-Sahara African Transformation and Development. Ilorin.

Wakefield, K.L. and Blodgett, J.G. (2002) 'Customer response to intangible and tangible service factors', Psychology and Marketing, Vol. 16 No. 1, pp. 51-68.

Yalch, R.F. and Spangenberg, E.R. (2000) 'The effects of music in a retail setting on real and perceived shopping times', Journal of Business Research (Elsevier Science Inc), Vol. 49, pp. 139-147.

Zeithaml, V.A. (1998) 'Consumer perceptions of price, quality and value: A means-end model and synthesis of evidence', Journal of Marketing, Vol. 52, pp. 2-22. 